\title{
Congenital alveolar capillary dysplasia
}

INSERM

\section{Source}

INSERM. (1999). Orphanet: an online rare disease and orphan drug data base. Congenital alveolar capillary dysplasia. ORPHA:210122

Cong enital alveolar capillary dysplasia (ACD) is a rare and fatal developmental lung disease characterized by respiratory distress in neonates due to refractory hypoxemia and severe pulmonary arterial hypertension. 